Fikrah: Jurnal Ilmu Aqidah dan Studi Keagamaan

ISSN 2354-6147 EISSN 2476-9649

Tersedia online di: journal.stainkudus.ac.id/index.php/fikrah

DOI: 10.21043/fikrah.v5i1.2258

\title{
Kritik Abdul Karim Soroush Atas Sistem Al- Faqih: Teks Agama, Interpretasi dan Demokrasi
}

\author{
Cahya Edi Setyawan \\ STAI Masjid Syuhada, Yogyakarta, Indonesia \\ cahya.edi24@gmail.com
}

\begin{abstract}
Abstrak
Soroush menggugat konsep "wilayah al-faqih" dalam sistem demokrasi agama di Iran. Konsep tersebut memberikan wewenang tunggal kepada Mullah dan ulama, sehingga fatwanya bersifat otoritatif. Soroush mengkiritik karena pemerintah hanya mengedepankan kepentingan negara dan menafikan kemaslahatan masyarakat. Kajian ini bebrsifat analisis interpretatif dengan memahami pemikiran Soroush tentang sistem pemerintahan di Iran, sehingga memberikan pemahaman tentang agama secara komprehensif yang membedakan antara agama dan tafsir agama. Soroush menggunakan teori hermeneutika kebebasan dalam membaca ajaran agama untuk menemukan ajaran egaliter. Kesimpulannya ialah "wilayah al-faqih" memperlambat adaptasi dengan perkembangan modern dan setiap putusan yang bersifat ideologi agama harus dipertimbngkan kembali karena bukan utusan Tuhan yang otoritatif.
\end{abstract}

Kata Kunci: Demokrasi, otoritas agama, soroush, kritik politik 


\begin{abstract}
Soroush criticized the concept of "al-faqih territory" embodied in the system of religious democracy in Iran. The concept gives Mullah and Ulama a sole authority. Al-faqih territory which means the leadership of a jihad is a form of Syiah politics that takes place in the Islamic Republic of Iran. The government policy in the name of "God's Voice" to punish a State case. According to Soroush, this is a misconception because the government just prioritizes the interests of the State and denies the public inspirations. On this basis, Soroush wants to give Iranians an understanding of religion more truthfully, so that the people are aware that Religion (text / revelation) and knowledge of theology is different. Soroush attempts at giving reconsideration of the status of "religious ideology" to the public in order to be able to criticize the concept of government in Iran that is "al-faqih territory".
\end{abstract}

Keywords: Democracy, religion authority, soroush, political critics.

\title{
Pendahuluan
}

Revolusi Iran pada tahun 1979 bermula dari kekejaman rezim Shah. Pasca revolusi, Iran menjadi inspirasi umat Islam golongan mengenah ke bawah yang tertindas oleh pemerintah yang mengatasnamakan agama sebagai justifikasi, sehingga dogma agama menjadi urgen untuk dikaji ulang sebagai media kritik dan konstruksi untuk melakukan perubahan dengan jalur agama. Fenomena kebangkitan agama tidak hanya mempengaruhi dunia Islam khususnya Timur Tengah, tetapi juga sebagian dunia pada umumnya. Dalam kajian modern, revolusi Iran dipandang unik dan menarik untuk dikaji karena terjadi pada abad 20, dimana dunia sudah mulai menjadikan logikan dan teknologi sebagai tanda kebangkitan modern. Dengan bahasa lain, revolusi Iran telah menciptakan sistem negara baru yang berdampak pada terbentuknya sistem al faqih. Pada wilayah ini, Iran telah menjadi percontohan terbentuknya negara yang menjadikan ajaran agama sebagai sistem perundang-udangan, sehingga relasi agama dan negara tidak dipandangan sebagai parsial.

Fenomena pengaplikasian ajaran agama dalam suatu negara menyebabkan timbulnya asumsi negatif, karena dianggap telah mencederai agama sebagai ajaran transendental yang datang dari Tuhan. Anggapan ini berangkat dari suatu kenyataan manusia yang berpotensi mengklaim otoritas Tuhan melalui interpretasi ajaran, seperti pemerintahan Shah di Iran yang dipandang otoriter karena mengakui fatwa-fatwa keagamaan sebagai sesuatu yang otoritatif dan diyakini kebenarannya sehingga 
mengesampingkan problematik dan etika yang berkembang di masyarakat. Dengan bahasa lain, fatwa-fatwa keagamaan telah menghadirkan semacam unethicalness atau ethical crisis di tengah masyarakat. Problem yang mengitari Shah disebabkan kuatnya pendapat-pendapat aliran fikih yang mendominasi setiap kebijakan yang diambil sebagai dasar justifikasi (Fadoil, 2013, p. 22). Pada saat yang sama, fikih menjadi sangat formal dan kaku di Iran sehingga dianggap sebagai dogma agama itu sendiri, buakn hasil interpretasi ulama. Asumsi tersebut menguatkan dominasi dan identitas kealiman seorang sehingga mengaburkan makna agama dan otoritas Tuhan, karena adanya sakralisasi fikih dalam pemahaman yang terdapat dalam aturan negara. Konsekuensinya ialah pemerintah Shah memanfaatkan kesempatan tersebut untuk kepentingan politik. Sehingga berdampak pada minimnya muatan etika dan minimnya hak asasi manusia pada perundang-undangan pemerintahan di Iran (Soroush, 2000, p. 31).

Menurut Soroush dominasi interprtasi agama yang berbentuk fikih menjadi sumber utama ketidakadilan secara material, karena undang-undang tersebut dikonstruksi dalam bingkai otoriter. Interpretasi dengan model demikian menafikan sumber otoritatif yang terdapat dalam al-Quran dan hadis, sehingga makna agama mengalami kekaburan, yaitu seorang tidak bisa lagi membedakan antara interpretasi agama dan sumber agama, karena pemahaman sudah diyakini sebagai agama itu sendiri. Keyakinan tersebut berdampak pada hilangnya muatan etika (unethical), seperti anggapan dasar bahwa pintu ijtihad telah ditutup dan tidak bisa menghadirkan hukum baru dalam masyarakat adalah bentuk tafsir otoriter. Asumsi demikian telah mencederai pemikiran manusia sebagai hamba yang dibekali akan sebagai pembeda dengan makhluk lainnya, menafikan peran akal sama halnya menghilangkan kritisisme berpikir. Fenomena tersebut diperparah dengan munculnya gerakan spiritual dari kalangan ulama konservatif yang menolak gerakan-gerakan rasional, sehingga menambah keyakinan bahwa agama dan interpretasi ajaran agama hanya hanya wewenang sebagian orang tertentu. Konsekuensi logis dari realitas tersebut ialah hilangnya pemikiran filsafat, hukum, dan sejarah Islam, karena sudah merasa tidak dapat dipahami kembali. Padahal problematika sosial-kemasyarakatan semakin meningkat. Akumulasi negatif dari asumsi-asumsi klaim otoritas ialah adanya perpecahan dari kalangan umat Islam sendiri yang terpecah menjadi kelompok-kelompok tertentu sebagai kritik atas 
kesewenangan kalangan dominan. Sehingga terma ulama menjadi terkotak-kotak, seperti ulama dari golongan pemerintah (governments religion) dan dari kalangan rakyat (peoples religion).

Munculnya polarisasi ulama berdampak pada fatwa-fatwa keagamaan. Bagi ulama yang berada dalam kawasan pemerintah, fatwa yang diputusan akan memberikan keberuntungan bagi pemerintah. Begitu juga sebaliknya, bagi ulama yang berada di luar pemerintah fatwa yang dikelurakn akan menjadi kritik pada putusan pemerintah. Lebih lanjut Soroush menjelaskan bahwa konsep wilayah al-faqih yang memberikan otoritas penuh kepada ulama merupakan peniruan atas ajaran Kristen dalam sistem pendeta. Soroush melihat, pemberian wewenang model wilayah al-faqih sama seperti gereja di Abad pertengahan. Dengan demikian, akan terjadi klaim otoritas yang menyebabkan munculnya tafsir yang memonopoli kebenaran dari para ulama yang tidak bisa dikritik. Padahal masyarakat terus berubah, dari pola dan karakternya yang disebabkan perkembangan ilmu pengetahuan dan teknologi yang mempengaruhi relasi sosial, ekonomi, politik dan agama. Sehingga adanya klaim otoritas para ualma dianggap sebagai skandal oleh masyarakat Iran.

Soroush berusaha memberikan pertimbangkan kembali tentang status ideologi agama dengan paradigma hermeutika tentang pemahaman agama. Hal ini dilatarbelakangi karena ketidakmampuan umat dalam mengembangkan pemikiran Islam akibat dari sakralisasi dan legitimasi ideologi yang dihasilkan ulama terdahulu tentang urusan agama (fiqih, akidah, syariah, dsb). Dengan bahasa lain, ada keterkaitan dan hitorical logic (keterpengaruhan sejarah) pola keagamaan yang berkembang di dunia Islam-terutama Iran-dan diyakini sebagai kebenaran abadi. Padaha hal tersebut akan menghambat perkembangan Islam. Lebih lanjut Soroush berpandangan bahwa produk ideologi yang diketahui dan diinterpretasi oleh manusia berdasarkan pemahaman pribadi tentang wahyu Allah, yang mana pemahaman tersebut hanyalah hasil pemikiran manusia bukan wahyu Tuhan. Ini berarti ideologi tersebut masih bisa dianalisis dan dilogikakan apabila tidak sesuai dengan perkembangan zaman. Dari sinilah muncul pemikiran Soroush tentang perlunya melakukan pemisahan antara wilayah Agama (keyakinan) dengan politik (negara), antara dimensi transenden (sakral) dengan yang imanen (profan). 
Menurut Abdul Karim Soroush yang dikutip oleh Fadoil (Fadoil, 2013), pemerintah harus bersikap demokratis, yaitu tidak harus mendominasi fikih sebagai undang-undang. Meskipun dominasi interpretasi agama-terutam fikih-mendominasi pemerintahan tidak mengimplementasi secara total, karena berdampak pada status warga negara yang tidak semua meyakini dan memeluk agama Islam. Adapun interpretasi keagamaan yang dijadikan sebagai justifikasi harus diinterpretasikan dan dikembangkan dengan menggunakan cabang-cabang ilmu pengetahuan agama dan nonagama. Karena hukum Islam harus disesuaikan dengan pemahaman masyarakat terhadap agama. Pemerintahan religius yang berjalan tanpa persetujuan masyarakat dan membelenggu hak-hak yang dimiliki masyarakat akan membuyarkan konsepsi keadilan dan akan kehilangan legitimasinya. Soroush tidak mengidentifikasikan demokrasi dengan kultur Barat tertentu sebagai suatu kekuatan asing yang harus dilawan. Dia menganggap demokrasi sebagai bentuk pemerintahan yang cocok dengan berbagai kultur politik, termasuk kultur politik Islam

\section{Metode Penelitian}

Kajian ini bersifat kualitatif dengan menggunakan analisa induktif yang menginterpretasikan dari objek yang bersifat khusus untuk ditarik pada simpulan yang bersifat umum (Anwar, 1998), dimana peneliti menjadi instrumen kunci dalam meneliti objek secara alamiah. Sedangkan model penelitian ialah kepustakaan (Library Research) yang mengkaji gagasan dari seseorang atau bersifat teoritis dengan penekanan atas data yang bersifat literatur yang mempunyai relevansi dari objek yang dikaji (Hadi, 1983). Dalam mengelola data dapat diambil dari tulisan, gambar atau karya seseorang yang mempunyai relevansi (Sugiyono, 2005).

\section{Histiografi dan Geneologi Intelektual Abdul Karim Soroush}

Abdul Karim Soroush lahir pada 1945 di Teheran Selatan, Iran. Hari kelahiran Soroush bertepatan dengan hari Asura tahun 1324 H. (Badarussyamsi, 2015, p. 73). Atas dasar inilah orang tua Soroush memberi nama Husayn Haj Farajullah Dabbagh. Nama Abdul Karim Soroush itu adalah nama yang digunakan sebagai identitas saat Soroush mempublikasikan karyanya. Nama Husayn dalam tradisi Syiah adalah nama suci, 
karena Imam Husayn, cucu nabi Muhammad SAW, meninggal pada tanggal 10 bulan Asyura. Setelah menamatkan pendidikan dasarnya di Qaimiyyah School, Soroush melanjutkan sekolah menengahnya di Mortazavi High School lalu pindah ke Alavi High School. Alavi merupakan sekolah yang mampu berkembang dan mapan (established) ketika dipegang oleh dua pengusaha yang cukup terkenal yakni Asghar Karbaschiyan dan Reza Rouzbeh. Di Alavi, Soroush belajar tentang persoalan-persoalan agama. Apalagi setelah dibuka kelas reguler dan Reza Rouzbeh, yang merupakan alumnus universitas dan seminary di Qum, berposisi sebagai pengajar mata kuliah Islamic Law (hukum Islam, fiqih) serta exegesis (tafsir) (Soroush, 2001, p. 23).

Setelah menyelesaikan sekolahnya, Soroush mengikuti tes masuk Universitas Teheran dengan mengambil jurusan fisika dan farmasi. Soroush lebih memilih jurusan farmasi atas rekomendasi Rouzbeh. Soroush belajar filsafat Islam pada Muthahari ketika belajar di universitas Teheran. Komentar yang di berikan Muthahhari atas karya Thabathaba'i (ushul-e falsafe wa rawish-e rialism) memberikan sebuah pencerahan bagi. Begitu pula ketika membaca Tafsir al-Mizan yang juga karya Thabathaba'i. Sayangnya Mutahhari hanya sempat mengajarinya dalam waktu yang sebentar. Namun, Mutahhari memperkenalkan Soroush kepada salah satu muridnya, seorang ulama yang juga imam di salah satu mesjid Teheran. Dari imam tersebut, Soroush belajar filsafat Islam selama beberapa tahun dan merasakan manfaat dan menyelesaikan studi di Universitas Teheran selama 6 tahun.

Setelah meraih gelar dalam bidang farmasi, Soroush melewatkan masa 2 tahun untuk menjadi tentara sebagai bentuk kewajiban warga negara. Setelah itu menjadi pimpinan laboratorium yang bergerak dalam penelitian produk makanan, toilettries dan alat-alat kesehatan di Buhsehr. Pekerjaan ini lakoni selama lima belas bulan dan kemudian kembali ke Teheran dan mulai bekerja di Laboratorium Kontrol Kesehatan, tetapi tak lama kemudian kembali ke London untuk mengambil studi baru dan agar menjadi lebih familiar dengan dunia modern. Soroush menggunakan kesempatan pertamanya untuk mengambil gelar MSc sebagai analis kimia, yang telah menjadi spesialisasi keilmuannya. Setelah menyelesaikan studi di Universitas London, Soroush kemudian melanjutkan pendidikannya ke Chelsea College di London, selama lima tahun. Di Universitas ini, mendalami masalah sejarah dan filsafat sains. Pada masa itu 
Soroush bersama aktivis Iran lainnya yang belajar di Inggris dan tergabung dalam Muslim Youth Association (MYA) giat mengkampanyekan perlawanannya terhadap rezim Syiah (Bagir, 2002, p. 11).

Beberapa kolega Soroush dari Afrika menganjurkan Soroush dan kawannya dari MYA untuk menjadikan imam barah yang berada di London Barat sebagai pusat aktivitas. Tempat inilah yang sering didatangi oleh pelajar Islam Iran di Inggris, terutama pada saat-saat menjelang terjadinya revolusi. Tokoh-tokoh besar dan aktivis dari berbagai belahan Eropa dan Iran, datang serta memberikan ceramah di tempat ini, termasuk Ayatullah Behesti dan Murtadha Mutahhari. Di Inggris, pidato-pidato Abdul Karim Soroush dicetak dalam pamflet dan buku. Pada awal memberikan ceramah yang merupakan seri tulisannya yang berjudul "Dialectical Antagonisme” (Iazad-Dialektiki), sebagai usahanya untuk mencoba menghadang berkembangnya pengaruh aliran kiri, terutama dari Mujahidin Khalq yang berhasil menarik hati dan pikiran banyak aktivis mudah melalui ideologi Marxisnya. Buku pertama Soroush yang dipublikasikan di Iran saat masih berada di London berjudul "Dialectical Antagonism" yang merupakan kumpulan ceramahnya di Imam Barah.

Pada saat yang sama, Soroush mengarang buku yang berjudul "The Restless nature of the World" (Sifat Dinamis Alam Semesta, Nahad-e Naaram-e Jahan) yang berisi tentang "Harkat-e Johari" (Gerak Substansial). Dalam buku ini Soroush mencoba mengemukakan dasar-dasar dari filsafat Islam, yakni tauhid (Monotheism) dan hari kebangkitan (Maad, Resurection) dari gerak substansial dan menyajikan pemikiran Mulla Sadra sebagai basis filosofis yang kuat bagi objek-objek keimanan. Pasca meletusnya revolusi, Soroush kembali ke kampung halamannya dan bergabung dengan college pelatihan guru. Belum genap satu tahun bergabung, muncullah gerakan yang menghendaki ditutupnya beberapa universitas, karena ada indikasi lembaga pendidikan ini telah terkontaminasi oleh model pendidikan Barat. Tidak lama setelah itu, dibentuklah Institut Revolusi Kebudayaan oleh imam Khomeini yang terdiri dari 7 orang anggota termasuk Soroush sebagai anggota.

Soroush kemudian kembali aktif memberikan ceramah di Masjid Imam Shadiq di Teheran Utara. Ceramahnya kaIi ini berisi seputar analisis terhadap kandungan Nahj 
AI--Balaghah (Kumpulan ucapan, pidato dan surat Ali bin Abi Thalib). Meskipun banyak mendapat intimidasi dari berbagai pihak, terutama kalangan yang loyal terhadap Ayatullah Khomeini, Soroush tidak berhenti untuk menularkan ide dan gagasannya. Bahkan pada tahun 1990, Soroush dan beberapa rekannya mendirikan majalah bulanan Kiyan, yang diperuntukan bagi mereka yang mempunyai visi konstruktif dalam pengembangan wacana agama dan intelektualitas. Tema-tema yang cukup sensitif di negara Iran seperti pluralisme agama, hermeneutika, Civil Society, toleransi dan demokrasi dipublikasikan melalui majalah tersebut. Dalam hal ini Soroush dan kawankawannya menjadikan majalah Kiyan sebagai corong atau media dalam menyampaikan gagasan tentang relasi agama dan negara, serta menjadi wadah bagi para pemikiran keislaman yang peduli atas ide-ide keislaman dan spirit kebebasan.

Menurut Farhang Rajaee yang dikutip oleh Fahmi Farid (2010, pp. 33-35), secara ideologis Soroush pernah berafiliasi dengan gerakan revivalis Islam dan mengusung semangat pelestarian nilai-nilai Islam di Iran, semenjak duduk pada jenjang pendidikan formal di tahun 1990 an. Meskipun dalam perjalanan intelektualnya Soroush didiskriminasi dan diintimidasioleh pengikut Khomeini, tetapi Soroush masih menilai sosok Khomeini adalah orang yang tekun dan sebagai manifestasi terbaik yang berhasil menggabungkan paradigma filsafat, mistisisme, dan jurisprudensi. Gagasan Soroush pada fase ini lebi banyak menyoal tentang bahasa Marxisme dan ajaran Islam, yaitu Soroush menilai bahwa agama tidak dapat menjadi bagian dari gerakan Marxisme yang menggambarkan kekejaman. Oleh sebab itu, Islam harus berdiri sendiri dengan ajarannya yang ideal. Jauh sebelum itu, Soroush pernah mempublikasikan buku yang berjudul 'Satanic Ideology' yang salah satunya menyerang ideologi Marxisme yang dianggap sebagai penghalang atas kemajuan Islam, karena Marxis telah mengajarkan tentang komunisme.

Pada fase selanjutnya gagasan Soroush berubah dengan signifikan, yaitu resim Islam yang setiap putusan hukum didominasi oleh paham fikih telah menutup kebebasan dalam mengekspresikan nilai agama. Pada posisi tersebut wilayah fakih menjadi problematis, karena ulama hanya menjadi corong dan wadah dari setiap kebijakan yang diambil oleh pemerintah Islam, sebagai konsekuensi ialah negara tidak bisa terbuka atas paham lain dan tidak menghilangkan makna agama itu sendiri dalam 
kehidupan bersama. Paham demikian telah memproduksi tafsir-tafsir otoriter dan melahirkan praktik despotisme dan diktatorisme. Tetapi bagi Soroush, putusan tersebut harus dilawan dengan beberapa gagasan.

Sejak tahun 2000, Soroush menjadi Dosen tamu di Harvard University, dan memegang mata kuliah Islam dan Demokrasi, Studi Quran dan Filsafat Hukum Islam. Dan juga mengajar Filsafat Politik Islam di Princeton University dan Wissenschaftkolleg Berlin, Jerman. Sebagai seorang intelektual, Soroush tidak hanya membuktikannya dengan menelurkan berbagai karya tulis, namun pengakuan itu juga didapat dalam bentuk penghargaan. Pada bulan April 2004, Soroush bersama Sadik Jalal al-Azm (Syiria), Fatima Mernisi (Maroko) terpilih menjadi penerima penghargaan Erasmus Prize yang digagas oleh Praemium Erasmianum Foundation. Penghargaan ini diberikan kepada seseorang atau institusi yang telah memberikan kontribusi signifikan dalam mewarnai dan beradaptasi dengan kultur Eropa, masyarakat dan ilmu pengetahuan sosial. Ketiga intelektual muslim tersebut berhak menerima 150.000 Pounds, yang diberikan langsung oleh Pangeran Bernhard di Amsterdam Belanda.

Keberhasilan Soroush menyabet penghargaan tersebut dikarenakan dkecakapan memadukan agama dengan modernitas. Secara kebetulan, Erasmus Prize untuk tahun 2004 mengambil tema "Agama dan Modernitas". Tema ini didasarkan atas berkembangnya politik dan masyarakat yang cukup memberikan peluang bagi semua lapisan dalam memulai memperdebatkan kembali relasi antara agama dan modernitas. Selain Erasmus Prize, Soroush juga pernah menerima penghargaan sebagai "Muslim Democrat of the Year" untuk tahun 2004 dari Centre for the Study of Islam and Democracy (CSID) di Washington DC, Amerika. Pada bulan April 2005, Soroush terpilih menjadi salah satu dari 100 orang yang paling berpengaruh di dunia versi majalah TIME. Penghargaan tersebut diberikan kepada mereka yang memiliki talenta untuk melakukan transformasi di dunia. TIME menyebut Soroush sebagai "Irans Democratic Voice". 


\section{Teks Agama dan Pengetahuan Ilmu Agama: Kontruksi Pemikiran Abdul Karim Soroush}

Soroush menggunakan pendekatan hermeneutika kebebasan ketika menginterpretasikan ajaran agama dan memahami pengetahuan agama, karena kebasan menjadi dasar untuk menemukan kebenaran. Adapun menghindari kebebasan menjadi musuh kebenaran dan tempat pembiakan ide-ide yang salah. Orang-orang yang takut pada kebebasan adalah mereka yang mencintai ide-ide lemah, sedangan para pencinta kebenaran sangat mencintai kebebasan. Kebebasan di sini erat kaitannya dengan nalar (reason). Karena manusia adalah makhluk rasional yang cendrung menginginkan kebebasan. Dalam hal ini, nalar menjadi sumber inspirasi dan wadah dalam mencari kebenaran. Penggunaan akal sebagai media kritis dalam mencari kebenaran akan menemukan ruang yang komplik, misalnya kaum Nazi merendahkan demokrasi dan kebebasan publik karena pemuja Hitler yang didukung dan didasarkan pada kepatuhan buta dan tidak rasional (Soroush, 2000, hal. 91-93).

Soroush ingin membedakan antara agama yang bersifat transendental dengan pemahaman agama (ilmu agama). Agama (wahyu) secara hakiki mempunyai kebenaran mutlak, namun pemahaman manusia terhadap agama bergradasi dan bisa salah. Soroush mempunyai gagasan bahwa harus dibedakan antara Islam sebagai kebenaran dan Islam sebagai identitas. Dalam memahami agama harus mendasar kepada kerangka epistemologis yang digunakan. Perubahan menunjukan bahwa memahami agama tergantung dari cara pandang. Hal ini bisa dipahami dari analogi melalui cerita Jalaluddin Rumi tentang gajah dan orang buta, dimana masing-masing orang buta itu menyampaikan deskripsi gajah secara berbeda-beda sesuai dengan bagian tubuh gajah yang mereka raba dan rasakan.

Soroush mempunyai teori berfikir sebagai berikut: Pertama, Expansion and Contraction Theory (Penyusutan dan pengembangan pemahaman keagamaan) dalam membedakan agama dan pemahaman ilmu keagamaan (Bagir, 2002, hal. 21-23). Menurut Soroush hakekat dari teori pengembangan dan penyusutan pemahaman keagamaan adalah bahwa ada satu fase di mana pemahaman seorang tentang agama itu berkembang (expansion), juga ada masa di mana pemahaman kita terhadap agama 
menyusut (contraction). Semuanya mungkin terjadi karena perbedaan kacamata dalam memandang agama. Menurut Soroush umat Islam belum bisa membedakan agama (aldin) dan pemahaman keagamaan ( $m a^{\prime}$ rifat al-din). Perluasan yang dimaksudkan bukan berarti bahwa ilmu pengetahuan buatan manusia menggantikan agama (Wahyu Allah). Begitu juga penyempitan bukan berarti agama memiliki peran kedua terhadap ilmu pengetahuan. Namun sebaliknya, bahwa kumpulan pengetahuan yang telah diakumulasikan oleh akal manusia menjadi pembimbing di dalam penyempurnaan dan pengembangan pemahaman manusia terhadap agama. Terjadi proses interdisipliner keilmuan dalam hal ini baik antar keilmuan agama, atau agama dengan ilmu sains dan sosial (Bagir, 2002).

Kedua, Basthu al-Tajribah al-Nabawiyah, yaitu tentang perilaku. Seorang dipilih sebagai Nabi bukan karena status sosial, tetapi pengalaman dan perilaku yang menyebabkan seseorang layak menjadi Nabi. Dengan bahasa yang lebih mudah bahwa, para Nabi memiliki cara masing-masing untuk mendekat pada Tuhan, cara-cara tersebut merupakan sifat Nabi yang sudah melekat sebelumnya untuk mendekatkan diri kepada Tuhannya. Dengan demikian, bisa dikatakan sifat kenabian tidak hadir dari titik nol tetapi hadir karena ada sistem kausalitas yang melatar belakanginya. Jadi menurut Soroush Nabi tidak diutus langsung oleh Allah, melainkan gelar kenabian dianalogikan sebagai sebuah jabatan dari Allah yang mana diperoleh dengan proses kualitas kinerja yang baik. Pada wilayah ini sebenarnya Soroush ingin menampakkan sikap para Nabi yang selalu dibalut dengan sikap egaliter, kasih sayang dan lain sebagainya. Sehingga para pengikutnya dapat mengambil pelajaran dalam menjalankan hidup bersama orang lain.

Ketiga, Al-Dzatiy wa al-Aradli fii al-Adyan. Istilah tersebut digunakan Soroush untuk menamai bagian orisinil (al-Dzati) dan yang dihadirkan (al-Aradli) dalam agama-agama. Keduanya merupakan bagian tak terpisahkan, seperti simbiosis mutualisme. Tanpa agama tak bisa dipahami, apalagi dipraktekkan. Dalam hal ini ada dua wilayah yang harus disadari oleh seorang dalam memahami agama, yaitu yang otoritatif dan yang otoritarian. Wilayah yang pertama membaca agama sebagai sumber ajaran murni yang harus dipatuhi dan bernilai transendental, seorang tidak bisa mengkritik dan menyoal ajaran-ajaran yang ada pada wilayah ini, seperti jumlah ayat al 
Quran, ketetapan shalat, haji dan lain sebagainya. Pada wilayah kedua agama harus dipahami sebagai realitas sosial, yaitu agama dipahami secara histori sampai interpretatif karena pada wilayah ini agama menjadi sesuatu yang temporan yang bersifat relatif. Membedakan keduanya akan memberikan kesadaran historis dan ideologi dalam memahami ajaran agama. Menurut Soroush menyimpulkan esensi Islamnya sendiri yaitu Islam mempunyai perangkat-perangkat yang bisa dipahami dan seorang muslim harus menemukan dirinya dengan berpegang teguh pada ajaran murni dalam Islam.

Keempat, Al-Din fii al-Had al-Adna wa al-Ala. Perumpamaan tentang evolusi pemahaman dari yang ala kadarnya menuju kadar tak terbatas, dari yang asalnya fisik menuju yang metafisik. Dari proses itulah kearifan pemahaman terekam dengan mudah. Artinya agama mempunyai wilayah obyek kajian konkret dan abstrak, yaitu pada awalnya kajian agama berangkat dari yang konkret menuju yang abstrak seiring dengan proses spiritual. Seperti seorang hamba tidak akan pernah merasakan ketenangan jiwa apabila hanya melakukan shalat sekali saja, namun harus dikerjakan berulang-ulang dan terus menerus hingga mampu merasakan ketenangan itu dengan sendirinya. Proses kejiwaan yang bersifat material tidak menjamin seorang akan merasakan ketenangan dalam beragama dan tidak berdampak akan kehadiran Tuhan. Relasi ini menandakan bahwa agama tidak hanya bersifat logis tetapi juga spiritual, pada aspek spiritual seorang harus bersungguh meyakini pada yang tidak kasat mata, seperti kehadiran Tuhan, adanya neraka, surga dan lain sebagainya. Adanya sesuatu yang kasat mata bukan berarti meyakini sesutu yang fana, tetapi meyakini bahwa kekuatan logika hanya bersifat relatif, tidak bisa mengetahui sampai pada akar sesuatu keculai dengan rasa. Konsep ini berlaku juga ketika akan menetapkan hukum Islam, karena tidak semua hukum dapat dilogika. Pada wilayah tertentu hukum bersifat tetap dan kekal, seperti shalat dan lain sebagainya. Tetapi pada saat tertentu hukum agama harus relevan atas perkembangan dan problem masyarkat.

Kelima, Al-Islam, al-Wahyu, al-Nubuwwah. Sifat turunnya wahyu kepada Nabi. Tujuannya menjernihkan dan menempatkan wilayah yang seharusnya, yaitu mana yang berposisi sebagai pengikut dan siapa panutannya. Maksud dari teori ini adalah turunnya wahyu selalu mengikuti kondisi Nabi dan umat muslim pada masa awal. Terkait dengan 
turunnya wahyu hanya Allah yang mengetahui, namun kepribadian Nabi ikut andil dalam turunnya. Karena Nabi tidak mampu untuk menangkap seluruh esensi wahyu, sehingga Allah menyesuaikan dengan keadaan Nabi. Dengan bahasa yang lebih sederhana ialah wahyu tidak turun dalam ruang hampa dan kosong, tetapi wahyu turun disesuaikan atau menjadi solusi dari problematik yang berkembang pada masyarakat Arab awal yang dihadapi Nabi. Dengan demikian, wahyu harus dipahami sebagai realita yang berkembang. Meminjam teori evolusi wahyu yang digagas oleh Arkoun, bahwa wahyu mempunyai tiga wajah, yaitu sesuatu yang abstark dan fundamental, sesuatu yang mempunyai relasi dengan sejarah, sehingga wahyu dianggap bagian dari sejarah Arab awa dan wahyu sebagai korpus terutup yang sudah menjadi bahan baku yang tidak dapat dirubah, ditambah maupun dikurangi. Oleh sebab itu, pemikiran Soroush termasuk bagian keuda, yaitu memahami wahyu sebagai realita dan kesadaran sejarah Arab dan Islam.

Keenam, Khatamiyyah al-Nabiy. Soroush membedah tentang pamungkas kenabian yang melekat pada Nabi Muhammad saw. Dalam prosesnya akan ditemukan kesimpulan bahwa dalam diri Nabi ada dua dimensi yang saling berkaitan, yaitu alSyakhsiyyah al-Nabawiyyah al-Haqiqiyyah danal-Syakhsiyyah al-Nabawiyyah alHuquqiyyah. Soroush berpendapat bahwa yang paling pamungkas adalahalSyakhsiyyah al-Nabawiyyah al-Huquqiyyah. Dimensi hakikat kenabian masih terbuka lebar untuk umatnya, umat Nabi saw bisa menjadi Nabi hanya dalam lingkup teori dan perilaku, tidak dalam penetapannya secara umum. Soroush menganggap bahwa kebanian tidak tertutup seperti yang dipersepsikan oleh kebanyak ulama. Hal ini memberikan pengertian bahwa ajaran agama tidak bersifat tertutup dan final, tetapi harus dipahami dengan beragama pendekatan dan metode yang relevan. Teori-teori atau perilaku tentang kenabian masih terbuka bagi siapa saja, karena Nabi Muhammad sebagai al-Syakhsiyyah al-Nabawiyyah al-Haqiqiyyah bersifat kekal dan final, tetapai sebagai al-Syakhsiyyah al-Nabawiyyah al-Huquqiyyah menjadi percontohan awal dalam berlaku agama, sehingga agama dapat bersanding dengan apa dan siapa saja dan dapat memberikan solusi atas problematik yang berkembang di masyarakat masing-masing.

Karakter atau ciri mendasar dari agama dan pemahaman keagamaan menurut Soroush bisa dilihat dalam beberapa hal. Pertama, agama atau wahyu selalu bersikap 
silent. Artinya wahyu hanya disampaikan secara face to face pada hamba yang ditunjuk oleh Tuhan sebagai penerima wahyu seperti Nabi Muhammad, kemudian diutus untuk menyampaikan kepada seluruh umat manusia. Pada wilayah ini, wahyu bersifat rahasia yang tidak dapat diketahui oleh banyak orang termasuk sahabat Nabi sendiri, karena wahyu hanya disampaikan dan diturunkan kepada Nabi, seperti yang terdapat dalam salah satu surah al Quran yang menyatakan bahwa Allah tidak akan berfirma kecuali wahyu yang disammpaikan dengan cara menyamarkan dibalik hijab atau melalui malaikat Jibril. Oleh sebab itu, wahyu bersifat privasi yang tidak diketahui orang banyak. Tidak ada yang mengetahui apa yang disampaikan Allah kepada Muhammad. Nabi Muhammad-bisa saja-hanya mampu menangkap sedikit esensi dari wahyu itu dan hanya Allah yang Maha Mengetahui segala hal ghaib. Al-Quran hanya representasi wahyu, esensi yang sesungguhnya beserta rahasia-rahasia hanya Allah yang mengetahui, manusia hanya mampu menduga-duga, menafsirkan dan sebagiannya dengan kemampuan akalnya. Jadi Soroush berpendapat apa yang ditafsirkan manusia (ulama) itu belum tentu benar. Oleh sebab itu, penafsiran tidak semuanya benar dan tidak seluruhnya salah.

Kedua, ilmu pengetahuan agama bersifat relatif, dan setiap produk pengetahuan agama dipengaruhi anggapan dasar (presuppositions). Artinya ilmu pengetahuan itu produk manusia. Dalam menghasikan ilmu pengetahuan manusia dipengaruhi akalnya. Kemampuan berfikir dipengaruhi oleh latar belakang kehidupan, golongan, masyarakat, psikologis sendiri, seperti logika ulama teologi ketika menafsirkan Al Quran yang dipengaruhi keahlian dalam teologi, ulama fiqih berdasarkan pengetahuan fiqihnya, ulama tasawwuf berdasarkan keilmuan tasawufnya. Pada wilayah tersebut hasil pemahaman bersifat relative. Ketiga, ilmu pengetahuan terikat dengan waktu (agebound), dimana produk pengetahuan tidak bisa lepas dari masa yang mengitari, seperti fiqih yang diproduksi manusia yang disesuaikan dengan problematika masa. Oleh sebab itu sifatnya akan terus berkembang, ketika ada kejadia baru dimasa yang berbeda secara otomatis putusan fiqih harus berbeda dan disesuaikan dengan problem zaman.

Keempat, agama yang diwahyukan benar dan bebas dari kontradiksi, tetapi ilmu pengetahun agama bisa kontradiktif. Artinya kalau wahyu sudah jelas hanya Allah yang memiliki, namun ilmu pengetahuan agama dipengaruhi oleh tingkat pemahaman setiap 
orang yang berbeda. Perbedaan tersebut akan menjadi problem ketika dipertemukan dalam satu forum, karena akan mempertahankan kebenaran, seperti perseteruan tafsir QS al Quran al Maidah 51. Secara teorotis, problematika penafsiran atas ajaran agama akan terjadi ketika kliam kebenaran dilesatarikan dalam ranah publik, dimana pada sejatinya tafsir adalah produk atau proses dari interaksi, pemahaman dan pembaca seorang atas ajaran agama. Oleh sebab itu, menjadikan wahyu sebagai sumber kebenaran adalah mutlak bagi umat Islam, tetapi mempercayai dan meyakini tafsir sebagai wahyu harus dipertanyakan keyakinanya. Kelima, agama bersifat sempurna dan komprehensif, tetapi ilmu pengetahun agama belum tentu sempurna dan komprehensif. Keenam, agama bersifat transendental, tetapi interpretasi relatif dan profan (Soroush, 1998, hal. 245-246).

Prinsip-prinsip teori ekspansi dan kontraksi keagamaan digunakan sebagai bahan analisa atas ajaran agama, karena teori ekspanasi difokuskan untuk memahami agama dalam arti sempit yaitu wahyu (ontologi agama) tetap dan selalu benar. Pada wilayah sama, agama dipahami mengembang (epistimologi agama) dengan menganalisis ajaran agama menggunakan disiplin keilmuan yang sesuai dengan perkembangan zaman. Adapun hasil ijtihad tidak selesai artinya usul fiqh bersifat dzanni bukan qathiy. Dengan demikian, dibutuhkan sekularisasi ilmu, yaitu memisahkan tugas dengan latar belakang seseorang. Gagasan tersebut membutuhkan sinergitas antara theology (keimanan), spirituality (tasawwuf), dan epistimologi (keilmuan). Menurut Soroush pertemuan tersebut bertujuan untuk mendamaikan antara keabadian dan temporalitas, sakral dan profan, materi dan substansi, yang konstan dan varian, merubah tampilan luar (appearance) sambil menjaga spirit agama (Soroush, 2000).

Beberapa prinsip teori ekspansi dan kontraksi bertumpu pada pendekatan filsafat, yaitu prinsip koherensi dan korespondensi yang berhubungan dengan pemahaman dan ajaran agama. Manusia akan memahami agama sesuai dengan kapasitas keilmuan yang dimiliki. Jadi prinsip ini menekankan penguasaan manusia terkait dengan ilmu pengetahuan sebagai instrumen untuk memahami agama. Oleh sebab itu, basik keilmuan dan kepribadian seseorang mempengaruhi penciptaan keilmuan. Adapun prinsip interpenetrasi memahami latarbelakang pengetahuan akan 
menjadi pintu masuk dalam memahamai ajaran agama. Dalam hal ini, aspek tersebut dapat mempengaruhi orisinalitas keilmuan agama, seperti orang pandai bahasa Arab akan mudah memahami al-Quran dan hadis. Dan prinsip evolusi. Bertujuan untuk menelaah perkembangan keilmuan yang terus berevolusi (meluas dan menyempit), serta akan selalu menyesuaikan dengan kondisi masyarakat, yaitu ilmu agama ada yang menyempit seperti akidah, akan mengembang seperti fikih karena terpengaruh oleh perkembangan zaman (Kamali, 1995, p. 25).

Pada hakikatnya teori ini adalah teori interpretasi epistemologi yang merupakan bagian dari ilmu kalam, sebab berhubungan dengan teologi tentang sejauh mana asumsi dan ekspektasi dari agama kita sebelumnya mempengaruhi pemahaman kita tentang alQuran dan Sunah, Merupakan bagian juga dari Ushûl al Fiqh karena secara terperinci menjelaskan ilmu-ilmu yang dibutuhkan oleh hukum agama (fiqh) untuk menarik kesimpulan secara metodis (istimbat). Merupakan bagian dari Irfâni sebab teori ini menjelaskan tentang syariat, tarekat, dan hakikat sebagai tiga aspek yang penting dalam agama (Soroush, 2000, hal. 31-35). Soroush juga ingin menempatkan fiqih dalam posisinya yang sesuai, memisahkan bagian yang fundamentalis dari yang kurang fundamentalis, dan membedakan agama sebagai pengalaman pribadi dari agama sebagai institusi kolektif. Menurut Forough Jahanbakhsh, teori yang dikembangkan ini memberikan kontribusi yang vital sebagai sebuah struktur epistemologi (Badarussyamsi, 2015, hal. 56-81).

Teori ini juga melibatkan epistemologi, antropologi, dan kosmologi dalam membuka pintu agama atau menariknya dalam realitas kehidupan manusia. Keterlibatan komponen tersebut merupakan prasyarat bagi seorang muslim untuk memahami eksistensi doktrin agama. Hal demikain disebut dengan pluralitas dalam agama. Dalam setiap aura keagamaan, selalu kita temukan adanya logos, Nabi dan kitab suci. Inkarnasi atau sejumlah penjelmaan langsung dari alam keilahian atau pesan dari firman-Nya yang kemudian terkomunikasikan melalui medium yang sangat manusiawi dan alami, itu semua adalah penjelmaan yang otentik dari yang absolut, sehingga masing masing medium tersebut harus diyakininya sebagai mutlak, walaupun pada tataran relatif. Hukum-hukum, simbol-simbol dan monumen yang disakralkan, doktrin-doktrin yang dikeramatkan oleh otoritas-otoritas tradisional, doa-doa yang 
menjadi ruh agama, semuanya adalah absolut dalam dunia keagamaan, tetapi tidak absolut dan tidak sakral dalam dirinya sendiri. Keadaan inilah disebut dengan "relatively-absolute" (Hidayat \& Nafis, 2003, hal. 55-56).

Menurut Mahmoud Sadri, saat ini kontribusi terbesar yang telah diberikan oleh Soroush adalah pada tatanan ranah epistemologi, etika masyarakat dan kritisisme sosial. Soroush membawa ide-ide tentang yurisprudensi, hermeneutik, dan epistemologi pengetahuan untuk menjawab pertanyaan tentang sejauh mana kita harus mengambil peraturan yang disimpulkan oleh mufti (Islamic Jurisconsults) sebagai perintah Tuhan yang langsung dan literal (Sadri, 2001, p. 258). Dalam karya yang berjudul Reason, Freedom and Democracy in Islam Soroush banyak menawarkan model interpretasi hermeneutis dan teori-teori epistemologis (interpretive-epistemological theory) untuk melengkapi domain-domain pengetahuan Islam tradiosional seperti kalām (teologi Islam), uṣūl (teori jurisprudensi Islam), and 'irfān (esoterisme Islam)(Soroush, 2000). Teori tersebut mengungkapkan kepekaan Soroush dalam menggunakan beberapa pendekatan dalam memahamai Islam, untuk mengkonstruksi pemahaman agama yang komprehensif, tidak harus menjadikan historisitas sebagai satu-satunya sumber, tetapi harus melibatkan ilmu-ilmu lain yang mempunyai relevansi atau mendukung dalam memahami ajaran agama.

\section{Tanggapan Soroush terhadap Wilayah al-Faqih di Iran dan Gagasannya tentang Demokrasi Agama.}

Sorous mengkritik wilayat al-Faqih pada dua wilayah. Pertama, penentangan terhadap otoritas untuk menafsirkan kebenaran. Otoritas rezim Iran atas tiraninya telah menindas kesejahteraan masyarakat. Pada wilayah ini, Soroush menjadi subjek dalam memahami Islam dan menjadikan perilaku keislaman sebagai objek. Ketidaksetujuan Soroush atas sikap otoritatif yang dikembankan oleh pemerintah adalah bentuk kritis yang dikonstruk dari problem penafsiran. Pasalnya, pemerintah hanya menjadikan Islam sebagai alat justifikasi yang pada akhirnya melestarikan produk tafsir otoriter. Kedua, anakronisme sistem wilayah al-faqih yang dianggap telah memperlambat beradaptasi dengan modernitas. Dalam beberapa kesempatan Soroush selalu menempatkan pemahama agama dalam posisi yang diametral. Satu pembahasan yang 
menjadi contoh betapa nalar dikotomis begitu kentara dalam pemikiran Soroush adalah ketika mengenalkan pemikiran tentang agama sebagai identita dan agama sebagai kebenaran. (Soroush, 2000, hal. 1-12). Selain mengkiritisi kebijakan pemerintah yang menjadikan Islam sebagai alat justifikasi, Soroush juga memperhatikan wilayah al faqih yang mempunyai otoritas lebih dalam memahami ajaran agama. Fenomena tersebut menandakan ketertutupan atas pemahaman lain, sehingga penafsiran adalah mutlak dikuasi al faqih. Padahal agama yang merubah wajahnya berupa teks, memberikan peluang bagi semua manusia untuk memahaminya. Menutup tafsir sama halnya menjadi wakil Tuhan, sehingga teks agama dan interpretasi agama tidak mempunyai perbedaan sebagai konsekuensi ialah seorang akan dituntut untuk mematuhi. Pada wilayah ini agama tidak bisa menjalin relasi dengan dunia modern.

Dalam konsep wilayah al-faqih, para fuqaha mempunyai peran signifiakan dalam memutus sebauh hukum agama, karena dianggap sebagai orang yang berkompetesi untuk membuat keputusan agama. Meskipun secara teknis konstitusi menerima doktrin kedaulatan rakyat. Namaun pada tatanan realitas, kedudukan tertinggi terlatak pada Tuhan dan wilayah al-faqih. Meskipun dalam pemilihan presiden, kedaulatan berada di tangan rakyat, tetapi pada kenyataanya wilayah al-faqih masih menjadi yang utama dalam memutuskan hukum Tuhan, tanpa pertimbangan sosial. Model pemerintahan semacam ini pada kenyataannya menafikan nilai-nilai demokrasi dan Islam, seperti munculnya ketidakadilan, sewenang-wenang, otoriter, dan pelanggaran hak asasi manusia. Esposito mencatat, bahwa pembersihan dan penindasan di Iran pada awal 1980-an dan berulang pada akhir 1980-an memupuskan harapan para pendukung revolusi Iran dan orang-orang yang ingin merasakan keadilan Islam versi Iran. Model pemerintahan diskriminatif bagai rakyatnya yang awalnya dilakukan oleh raja, digantikan para ulama dengan pendekatan interpretasi negatif dari ajaran agama. Sehingga hanya aktor-aktor atau pemain-pemain politi yang berganti, bukan praktiknya. Penahanan, pengadilan sewenang-wenang, penyiksaan, sensor ketat, dan pengawasan oleh pasukan keamanan terus berjalan. Geng-geng jalanan Hizbullah menyerang para penentang, membubarkan rapat oposisi, dan melecehkan kaum perempuan. 
Wilayah al-Faqih merupakan ranah problematis karena ada banyak kesenjangan di dalamnya. Soroush melihat paling tidak ada tiga ranah yang menjadikan kesenjangan, yakni ruang waktu dan subjek. Wilayat al-Faqih harusnya diposisikan sebagai produk budaya (teks linguistik) atau bahkan (teks manusiawi) agar sesuai dengan fungsi dan tujuannnya untuk masyarakat. Sebagai solusi, Soroush menggagas ide tentang demokrasi agama. Soroush menolak tentang pemerintahan religious bebrbasis fikih atau teologi. Soroush menilai bahwa fikih adalah salah satu dimensi dalam agama, dan memahami agama semata-mata hanya fikih berarti reduksionis. Dan pada dasarnya, pemerintahan tidak perlu berbasis religi, misalnya harus berbasis Khilafah, berbasis Islam dsb. Menurut Soroush pemerintahan cukup menggunakan dan menerapkan nilainilai keislaman tanpa perlu harus menjadi Islam sebagai institusi yang diterapkan dalam putusan negara, karena nilai keislaman lebih baik bersanding dengan demokrasi, dibandingkan harus disebut dalam negara.

Perpaduan antara agama dan demokrasi akan memberikan khasanah yang lebih luas dan lebih bijak, dimana selain mempunyai landasan yang agamis, sistem pemerintah juga mempunyai dimensi epistemologi non-agama. Sehingga, dalam mengambil keputusan tidak terjadi proses eksklusif dari pemikiran pada hukum agama dan hasil yang dicapai lebih komprehensif terhadap proses putusan hukum agama (ijtihad al-fiqhi). Syarat demokratisasi pemerintah agama adalah menggunakan pendekatan sejarah dan memberdayakan pemahaman agama dengan menekankan peran nalar kolektif yang muncul dari partisipasi publik dan pengalaman manusia serta terwujud hanya melalui metode demokrasi. Gagasan tentang relasi agama dan negara digagas sebagai solusi untuk memutus rantai tafsir otoriter. Pendekatan agamis dalam mengelola pemerintah tidak menjadikan negara aman dan damai, karena harus melewati berbagai problem interpretasi. Begitu juga, menerapkan gaya sekuler, akan merubah wajah negera menjadi liberal yang merugikan beberapa kalangan. Dengan demikian, suatu keniscayaan merelasikan agama dan negara dalam satu bangunan konseptual, supaya terdapat nilai luhur bisa diaplikasikan dalam kehidupan bersama.

Pemerintahan demokrasi berfungsi sebagai arbiter (penengah) bagi masalah masyarakat, sedangkan pemerintahan agama melibatkan agama sebagai justifikasi tindakan dan arbitrasi. Agama tidak pernah menetapkan situasi secara independen, 
namun penetapan-penetapan situasi oleh agama banyak dikaburkan oleh berbagai penafsiran teks agama. Di sinilah peranan dari nalar yang sehat sangat diperlukan, yaitu untuk meyesuasikan pemahamannya mengenai agama dengan ilmu-ilmu yang lainnya. Logika yang menguraikan kebenaran, keadilan, kepentingan umum, dan kemanusiaan, yang menjadi dasar pijakan dalam menghidupkan ajaran agama. Menurut Soroush pemerintahan demokrasi agama tidak perlu melepaskan agama dalam kehidupan sehari-hari. Sebuah pemerintahan religius seharusnya menetapkan agama sebagai penuntun dan penengah (arbiter) bagi semua masalah dan konflik yang timbul.

Bagi Soroush, fikih hanya merupakan jawaban terhadap sejumlah masalah hukum dan tidak mencakup isu-isu yang lebih dalam seperti arti keadilan dan kebebasan. Sehingga, untuk menerangkan masalah keadilan dan kebebasan Soroush beralih kepada kalam. Menurutnya, keadilan mencakup konsepsi kemanusiaan tentang hakekat dan hak-hak manusia. Konsepsi ini harus sejalan dengan agama. Namun tidak cukup didefinisikan hanya berdasarkan naskah keagamaan semata. Soroush juga menjelaskan mengenai nilai yang diwujudkan dalam sebuah pemerintahan dan metode yang digunakan oleh pemerintahan tersebut. Demokrasi agama menurut Sorous, harus mewujudkan nilai-nilai keagamaan. Namun, untuk mewujudkan harus menggunakan nilai-nilai yang berkembang di luar agama, karena negara tidak hanya dimiliki identitas agama tertentu. Pemerintahan yang didominasi oleh agama tertetnu-apalagi bercorakan fikih-akan mengurangi hak asasi manusia dan juga akan mengalami kekurangan instrumen metodologis yang memadai untuk menjalankan pemerintahannya. Dalam hal ini, terdapat ruang kosong yang harus diisi dengan unsur di luar agama dalam menjalankan roda pemerintahan.

Soroush mengemukakan bahwa wilayat al-faqih adalah produk tertentu dari suatu masa, yang tentunya sangat terkait dengan pergolakan dalam masa tersebut. Wilayat al-faqih bermaksud untuk mengembangkan tongkat kepemimpinan pada masa kegaiban. Keterkaitan antara wilayat al-Faqih dengan ruang dan waktu itulah yang harus dilihat sebagai satu bentuk kesatuan yang utuh. Wilayat al-faqih sebenarnya ingin memadukan konsep kedaulatan rakyat namun harus dibatasi oleh kedaulatan orang yang dipercaya untuk menjadi pengganti imam pada masa kegaiban. Relativitas kebenaran yang ada dalam wilayat al-Faqih inilah yang menyebabkan sistem ini tidak 
dapat diklaim sebagai sebuah model ideal pemerintahan. Oleh sebab itu, wilayat alFaqih harus membuka diri pada dunia luar dan memasukan keilmuan lain (extra religious idea) sebagai pertimbangan dalam mengambil keputusan.

Soroush berpendapat bahwa penekanan itu harus diberikan bukan pada penyatuan (ittihad) ilmu pengetahuan agama dengan non-agama untuk mengislamkan yang non-agama, melainkan pada interaksi (irtibat) antara berbagai bidang tersebut (Soroush, 1998). Putusan hukum harus sesuai dengan pemahaman masyarakat. Demokrasi agama yang berjalan tanpa persetujuan masyarakat dan membelenggu hakhak masyarakat akan membuyarkan konsepsi keadilan dan akan kehilangan legitimasinya. Soroush tidak mengidentifikasikan demokrasi dengan kultur Barat tertentu sebagai suatu kekuatan asing yang harus dilawan. Tetapi menganggap bahwa demokrasi sebagai bentuk pemerintahan yang cocok dengan berbagai kultur politik, termasuk kultur politik Islam.

Soroush menolak dengan tegas pernyataan yang menyatakan Islam dan demokrasi tidak dapat dipersatukan. Lebih lanjut Soroush berargumentasi bahwa demokrasi tidak mengharuskan kaum beriman meninggalkan keyakinan, menyekulerkan iman, dan menghilangkan keimanan pada perlindungan Tuhan. Demokrasi agama memperbolehkan orang memeluk agama yang diyakini secara bebas, orang juga diperbolehkan memperkuat dan menyebarkan keyakinan. Soroush berpendapat bahwa dalam negara demokratis, baik kelompok muslim maupun nonmuslim tidak memperoleh hak asasi dari agama, melainkan hak- hak tersebut merupakan produk dari keanggotaan dalam kelompok umat manusia yang lebih besar. Karena agama bukanlah dasar dari hak, kelompok non-muslim tidak harus meninggalkan agama untuk menikmati hak-hak yang sama dalam masyarakat muslim. Demikian pula sebaliknya, umat muslim tidak harus meninggalkan kepercayaan untuk menerima hak-hak yang sama dengan masyarakat non- muslim. Soroush menilai terdapat tiga kesalahan yang dilakukan oleh para pengkritik demokrasi agama; pertama, demokrasi disamakan dengan liberalisme exstrem. Kedua, yurisprudensi agama (syariat) dipangkas dari fondasinya, dikutip di luar konteks, dan kemudian diajukan sebagai dalil. Ketiga, pemerintahan demokrasi agama disamakan dengan pemerintahan 
yurisprudensi agama (fikih) dan diserang dengan sebagai kesatuan monolitik. Ketiga asumsi ini secara tegas harus dinyatakan salah (Soroush, 1998).

\section{Simpulan}

Kesimpulan yang dapat diajukan ialah bahwa latar belakang munculnya pemikiran Soroush tentang penyempitan dan perluasan pemahaman agama ini disebabkan adanya ketidakpuasan dan kritik atas pemerintah Iran yang menberikan otoritas agama dalam pengambilan segala keputusan (Wilayah Al-Faqih). Disamping itu juga untuk merevolusi pemikiran masyarakat tentang pemahaman agama dan ilmu agama. Karena muslim rawan terjebak dengan dalih atas nama Tuhan untuk menghukumi sesuatu. Soruoush ingin memahamkan kepada masyarakat tentang apa itu agama dan apa itu ilmu agama dengan memberikan metodologi dan menggulirkan konsep pemerintahan demokrasi Islam yang lebih mensejahterakan masyarakat dengan beberapa langkah. Pertama, membedakan anatar agama dan pemahaman agama dengan menggunakan teori ekspansi dan konstraksi, kedua, Basthu al-Tajribah alNabawiyah,ketiga, Al-Dzatiy wa al-Aradli fii al-Adyan, keempat, Al-Din fii al-Had alAdna wa al-Ala, keilam, Al-Islam, al-Wahyu, al-Nubuwwah, keenam, Khatamiyyah alNabiy. Soroush mengkiritk wilayat al-Faqih pada dua wilayah, pertama penentangan terhadap otoritas untuk menafsirkan kebenaran. Otoritas rezim Iran atas tiraninya selama ini yang telah menindas kesejahteraan masyarakat, dan kedua anakronisme sistem wilayah al-faqih karena sikap lambatnya adaptasi dengan modernitas. Dalam beberapa kesempatan Soroush selalu menempatkan pemahaman agama dalam posisi yang diametral. Satu term yang menjadi contoh betapa nalar dikotomis begitu kentara dalam pemikiran Soroush adalah ketika mengenalkan pemikiran tentang agama sebagai identitas dan agama sebagai kebenaran. 


\section{Referensi}

Abdallah, U. A. (2010). "Memikirkan Agenda Pembaharuan Islam ke Depan" Makalah untuk Studium General (No. 3 Oktober). Cirebon.

Anwar, S. (1998). Metodologi Penelitian. Yogyakarta: Pustaka Pelajar.

Badarussyamsi. (2015). Pemikiran Abdul Karim Soroush tentang Persoalan Otoritas Kebenaran Agama. Islamica: IAIN Sultan Thoha Jambi, 10, 58-81.

Bagir, H. (2002). Potret Seorang Muslim Liberal. In A. Ali (Ed.), Menggugat Otoritas dan Tradisi Agama (pp. 11-27). Bandung: Mizan.

Fadoil, H. (2013). Konsep Pemerintahan Religius dan Demokrasi Menurut Abdul Karim Soroush dan Ayatullah Khomeini. Al-Daulah: Jurnal Hukum Dan Perundangan Islam, 3.

Hadi, S. (1983). Metodologi Research. Yogyakarta: UGM Press.

Hidayat, K., \& Nafis, M. . (2003). Agama Masa Depan: Perspektif Filsafat Perenial. Jakarta: Gramedia.

Kamali, H. (1995). The Theory of Expansion and Contraction of Religion: A Research Program for Islamic Revivalism (An Iranian Perspective).

Sadri, M. (2001). Sacral Defense of Secularism: The Political Theologies of Sprpush, Shabestari and Kadivar. International Journal of Politics, Culture and Society, 15, 285.

Soroush, A. K. (1998). The Evolution and Devolution of Religious Knowledge. In C. Kurzman (Ed.), Liberal Islam: A Souercebook (pp. 245-246). New York: Oxford University Press.

Soroush, A. K. (2000). Reason, Freedom and Democracy in Islam. New York: Oxford University Press.

Soroush, A. K. (2001). Menggugat Otoritas Agama. Bandung: Mizan.

Sugiyono. (2005). Memahami Penelitian Kualitatif. Bandung: Alfath Offset. 
Abdallah, U. A. (2010). "Memikirkan Agenda Pembaharuan Islam ke Depan" Makalah untuk Studium General (No. 3 Oktober). Cirebon.

Anwar, S. (1998). Metodologi Penelitian. Yogyakarta: Pustaka Pelajar.

Badarussyamsi. (2015). Pemikiran Abdul Karim Soroush tentang Persoalan Otoritas Kebenaran Agama. Islamica: IAIN Sultan Thoha Jambi, 10, 58-81.

Bagir, H. (2002). Potret Seorang Muslim Liberal. In A. Ali (Ed.), Menggugat Otoritas dan Tradisi Agama (pp. 11-27). Bandung: Mizan.

Fadoil, H. (2013). Konsep Pemerintahan Religius dan Demokrasi Menurut Abdul Karim Soroush dan Ayatullah Khomeini. Al-Daulah: Jurnal Hukum Dan Perundangan Islam, 3 .

Hadi, S. (1983). Metodologi Research. Yogyakarta: UGM Press.

Hidayat, K., \& Nafis, M. . (2003). Agama Masa Depan: Perspektif Filsafat Perenial. Jakarta: Gramedia.

Kamali, H. (1995). The Theory of Expansion and Contraction of Religion: A Research Program for Islamic Revivalism (An Iranian Perspective).

Sadri, M. (2001). Sacral Defense of Secularism: The Political Theologies of Sprpush, Shabestari and Kadivar. International Journal of Politics, Culture and Society, 15, 285.

Soroush, A. K. (1998). The Evolution and Devolution of Religious Knowledge. In C. Kurzman (Ed.), Liberal Islam: A Souercebook (pp. 245-246). New York: Oxford University Press.

Soroush, A. K. (2000). Reason, Freedom and Democracy in Islam. New York: Oxford University Press.

Soroush, A. K. (2001). Menggugat Otoritas Agama. Bandung: Mizan.

Sugiyono. (2005). Memahami Penelitian Kualitatif. Bandung: Alfath Offset. 